\title{
Elaboração e divulgação de e-books de guias experimentais com automatização e arduino para o ensino de física
}

\author{
Deise Silva Lima ${ }^{1}$, Luciene Batista da Silveira² \\ 1,2Fundação Universidade Federal de Rondônia (UNIR)
}

Palavras-Chave: Ensino de Física, Guias, Arduino, Robótica, e-Book.

\section{Introdução}

Um robô pode ser definido como um sistema autônomo que existe no mundo físico, pode sentir o seu ambiente e pode agir sobre ele para alcançar alguns objetivos. Essa definição pode parecer muito ampla, mas na verdade cada uma de suas partes é importante (MATARIĆ, 2014). A robótica é uma área de pesquisa que visa o desenvolvimento de robôs para, de algum modo, auxiliar o homem em tarefas complexas ou repetitivas (SILVA, 2009). Sendo, portanto, uma área que agrega várias áreas do conhecimento e que traz em si a interdisciplinaridade, podendo ser evidenciado na diversidade de setores em que robôs podem ser utilizados. Recentemente, a robótica chegou à escola. Nesse setor, a robótica toma uma nova forma, deixa de ser eminente para produção de robôs para se construir um novo mediador no processo de ensino aprendizagem (D'ABREU, 1999).

A união entre a robótica e educação tem todos os ingredientes para ter êxito. Primeiro, o robô, como elemento tecnológico, possui uma série de conceitos científicos cujos princípios básicos são abordados pela escola. Segundo, pelo fato de que robôs mexem com o imaginário, despertando o lado lúdico e desafiam a busca de maneiras para lidar com novas linguagens criando formas inovadoras de interação. $\mathrm{O}$ ambiente de aprendizagem em que o professor ensina ao aluno a montagem, automação e controle de dispositivos mecânicos que podem ser controlados pelo computador é denominado de Robótica Pedagógica ou Robótica Educacional. Que também apresenta-se na modalidade de Robótica com Sucata que trabalha com material reciclado. O uso da sucata é uma maneira de se construir protótipos robóticos a baixo custo (VIEIRA; VOLKIND, 2000).

Buscando ampliar o leque de ferramentas pedagógicas aplicadas à robótica na educação, a proposta desse projeto é criar roteiros experimentais didáticos de modelos de robôs como mediadores no processo de ensino aprendizagem na disciplina de Física.

\section{Metodologia}

O material instrucional que é apresentado neste trabalho tem como premissa a intenção de ser potencialmente significativo, com o objetivo de auxiliar de forma marcante o processo educacional.

Buscando ampliar o leque de ferramentas pedagógicas aplicadas à robótica na educação, e procurando promover a interação teoria/prática com o objetivo de facilitar a aprendizagem significativa de conceitos de Física, a proposta desse projeto é criar e utilizar:

- Roteiros experimentais didáticos como mediadores no processo de ensino aprendizagem na disciplina de Física.

- Um Roteiro com um Modelo de Espaço Oficina Pedagógica para as aplicações dos roteiros experimentais.

- $\quad$ E-books dos roteiros experimentais e modelo de Oficina Pedagógica.

Para a montagem de protótipos, utilizaremos a placa Arduino Uno R3 e peças de sucata de componentes de equipamentos eletrônicos que permitem a montagem de modelos robóticos com materiais de baixo custo.

\section{Resultados esperados}

A própria legislação referente à formação de professores da educação básica, ao estabelecer o perfil do professor a ser formado, aponta para a falta de identidade e de integração entre o

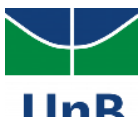


conhecimento do objeto do ensino e a transposição didática, o que constituiria em um distanciamento entre os cursos de formação e o exercício da profissão de professor no ensino médio. Erroneamente, a atividade docente é encarada como vocacional, que permitiria grande dose de improviso e auto formulação do "jeito de dar aula". (OSTERMANN; CAVALCANTI, 2010).

Como resultado do presente trabalho, foi elaborado e-Books com os roteiros experimentais pedagógicos com os protótipos didáticos. O produto educacional produzido como decorrência deste trabalho, será disponibilizado aos acadêmicos e professores interessados, com intuito de auxiliálos na sua prática pedagógica.

\section{Conclusões}

Esta pesquisa se propôs, como objetivo geral, elaborar um material didático para o ensino de Física em formato de e-book contendo roteiros experimentais, bem como guias com conteúdos e orientações didáticas para a utilização em aulas de Física que atenda profissionais na área de Ensino e permita a disseminação e a socialização da metodologia envolvida nos roteiros auxiliandoos na sua prática pedagógica.

As atividades foram pensadas de forma a tornar o estudante um participante ativo durante todo o processo de aprendizagem, estimulando-o a manifestar uma disposição de relacionar o material de maneira substantiva e não-arbitrária a sua estrutura cognitiva (MOREIRA, 2010).

Estima-se que esse projeto contribuirá para complementação de práticas de profissionais da área de Ensino de Física mostrando que o profissional que trabalha com a prática do projeto e de roteiros experimentais saberá lidar com ambiguidades, soluções provisórias, variáveis e conteúdos não identificáveis a priori. E que a partir deste produto educacional profissionais da área de Física tenham o apoio necessário para elaboração e execução de seus próprios roteiros.

\section{Referências}

D'ABREU, J. V. V. Desenvolvimento de Ambientes de Aprendizagem Baseados no Uso de Dispositivos Robóticos. X Simpósio Brasileiro de Informática na Educação - SBIE99, Curitiba, 1999.

MATARIC, M. J. Introdução à Robótica. 1 ed. São Paulo: Unesp/Blucher, 2014.

MOREIRA, M. A. Texto de apoio para a disciplina de pós graduação: Bases Teóricas e Metodológicas para o Ensino Superior, Porto Alegre: Instituto de Física, UFRGS, 2003 - 2009. Revisado em 2010.

OSTERMANN, F; CAVALCANTI, C. J. H. Teorias de Aprendizagem. Universidade Federal do Rio Grande do Sul, Instituto de Física, Texto introdutório, 2010.

SILVA, A. F. RoboEduc: Uma Metologia de Aprendizagem com Robótica Educacional. Centro de Tecnologia. Programa de Pós-Graduação em Engenharia Elétrica. Universidade Federal do Rio Grande do Norte. Natal, RN, Março de 2009.

VIEIRA, E.; VOLKIND, L. Oficinas de Ensino. O que? Por quê? Como?. Porto Alegre: EDUPUCRS, 2000. 